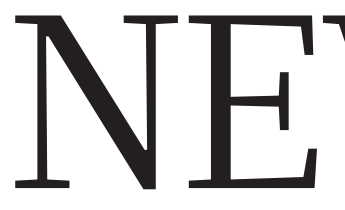

FLU Nature analysis highlights holes in global virus surveillance $\mathbf{p . 5 2 0}$
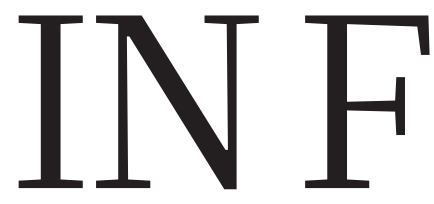

CHEMISTRY Millions of

molecules set free in public databases $\mathbf{p . 5 2 4}$

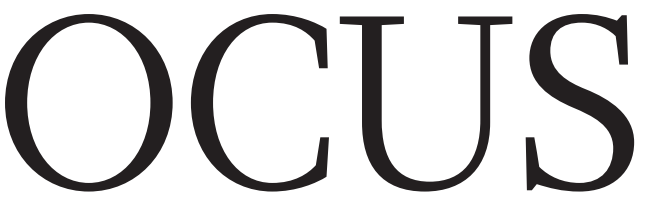

EXOPLANETS Weighing the Kepler candidates with Swiss precision $\mathbf{p . 5 2 2}$
AGRICULTURE Ways

to treat Africa's ailing soils $\mathbf{p . 5 2 5}$

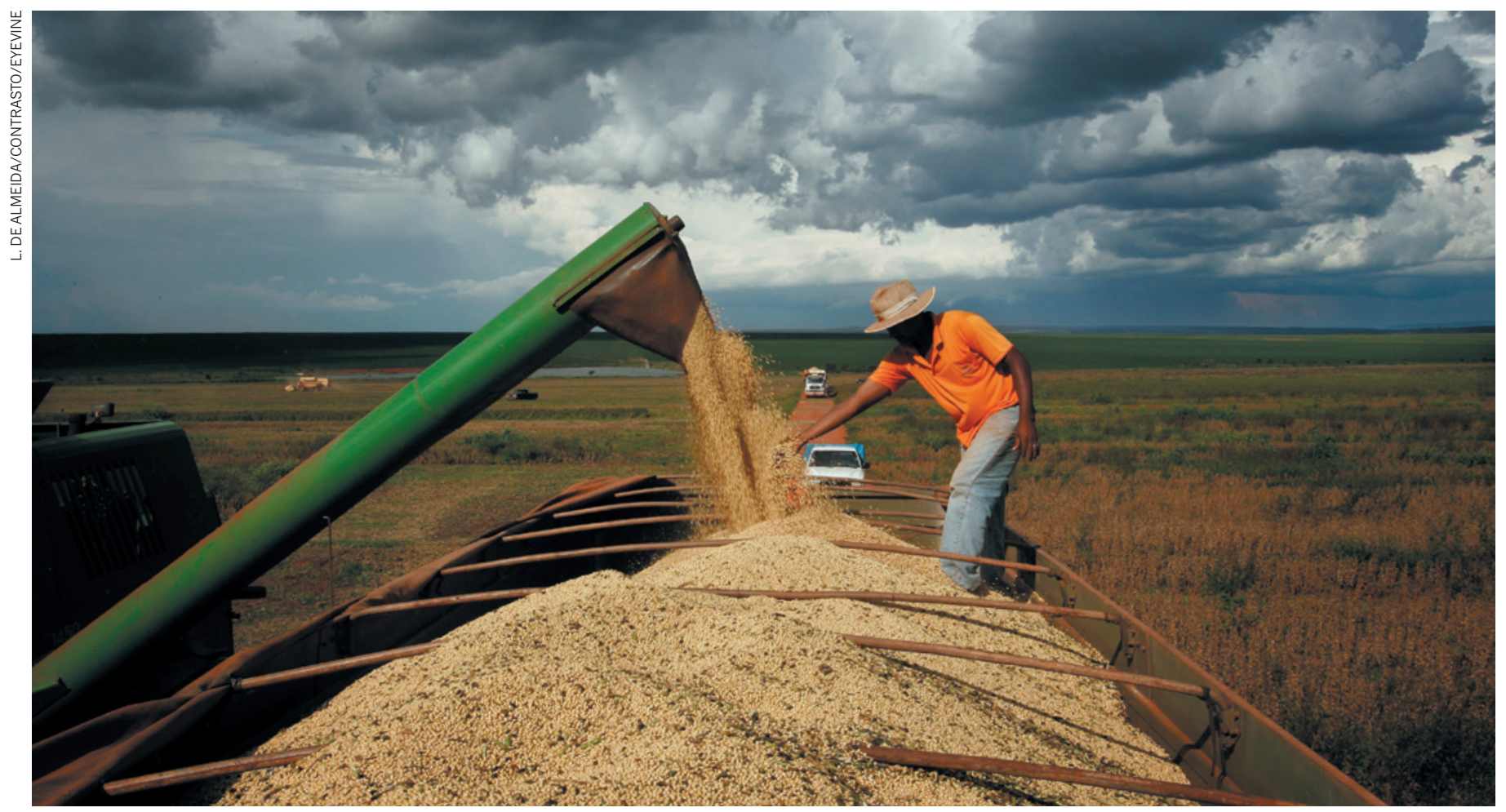

Soya growers in Brazil who sign up to proposed environmental standards would be able to increase the productivity of existing farmland and so limit deforestation.

\title{
ENVIRONMENT
}

\section{Farm focus for saving trees}

\section{Round-table talks aim to slow climate warming by transforming agriculture.}

\section{BY JEFF TOLLEFSON}

$\mathrm{T}$ The principle is seductively simple: to reduce carbon emissions, leave tropical forests standing. But a widely heralded approach in which rich nations would pay poorer ones to keep their forests intact has proved trickier to deploy than many had hoped. Now a consortium of scientists, environmentalists and industries is expanding the focus from preserving forests to tackling the main driver of deforestation: agriculture.

The United Nations forestry initiative known as REDD, for Reducing Emissions from Deforestation and Forest Degradation - was originally seen as a way of changing frontier economics by attaching a monetary value to standing forests, which take up carbon dioxide and stabilize the climate. Carbon payments would make it easier for landowners to earn a living without clearing more land. But despite years of negotiations and several billion dollars in commitments, little money has filtered down to those who live and work at the forest frontier. Where money has changed hands, it has happened mostly among governments, says Daniel Nepstad, a US ecologist who heads the international programmes for the Amazon Environmental Research Institute (IPAM), headquartered in Brasilia. As a result, he says, scepticism is rising among those who are supposed to benefit most.

Nepstad and others involved in the latest REDD effort see potential for faster progress by merging REDD initiatives with a series of 'commodity round tables', which bring multinational companies such as beverage firm PepsiCo, agricultural biotech giant Monsanto and retailer Walmart together with producers and environmentalists to negotiate environmental certification standards for products such as soya beans, palm oil, sugar cane and beef. These standards focus on everything from soil management to workers' rights, and include limits on deforestation. The idea is that producers who sign up and implement best practices will be able to increase productivity, command a higher price for their products and pressure competitors to raise their own standards. "REDD has become loaded down," Nepstad says. "Where it is moving forward 


\section{FOOD VERSUS FORESTS}

More sustainable farming of key crops could slow the rate of tropical deforestation. The map identifies countries and crops that offer the greatest gains.

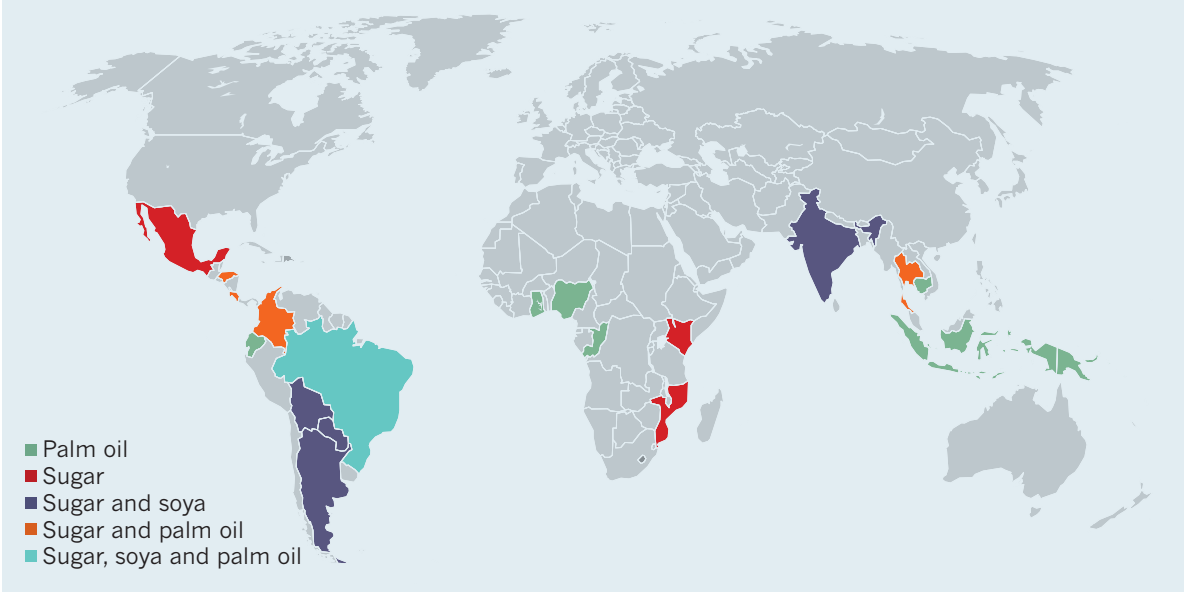

- most effectively is where it is moving together with rural development strategies."

IPAM leads a loose-knit consortium known as the Roundtable-REDD, which released an analysis on 28 March that identifies countries in which investing in projects for production of sugar cane, soya and palm oil could have the greatest impact on carbon (see 'Food versus forests'). With more than US\$4 million in seed money from Norway, the consortium plans to announce an initial round of projects in the run-up to the UN Conference on Sustainable Development in Rio de Janeiro (Rio+20) in Brazil in June.

Initially, consortium projects could focus on restoring abandoned agricultural lands and intensifying production on existing farms, ranches and plantations. This could involve accelerated replanting of palm plantations with high-yield varieties in Indonesia, or helping farmers and ranchers to access existing money for sustainable agriculture in Brazil. In the latter case, Nepstad says that the consortium is looking at ways to help those landowners who commit to round-table standards apply for subsidized government loans - worth some $\$ 1.7$ billion during the current growing season - so that they can improve soils and intensify their production or redevelop degraded fields instead of clearing new ones. The consortium is also looking at tackling overall greenhouse-gas emissions using carbon credits, which could be sold to private investors or companies seeking to offset their own emissions. Those funds could help farmers and ranchers to bring in better soilmanagement practices, make more efficient use of fertilizers or capture methane emissions for electricity generation.

\section{GAME CHANGER}

The programme's potential is highlighted by recent progress in Brazil, where Amazon deforestation has declined by $78 \%$ since a 2004 peak even as agricultural production continued to climb. Recent studies suggest that government enforcement and broader agricultural policies ${ }^{1,2}$ have played a part, but consumers and environmentalists have also contributed by pressuring major food suppliers to sign moratoria on the purchase of round-table model, which is already operating for some commodities, is similar. Although it is too early to see land-use changes in satellite data, the round tables do seem to be affecting the way many companies do business, says Holly Gibbs, an environmental geographer at the University of Wisconsin-Madison. "I don't know that it's a sea change yet," Gibbs says, "but they are definitely changing the rules and the norms and the way these industries operate."

Nonetheless, even advocates acknowledge that it is difficult to achieve consensus on environmental standards in a room of producers, major food companies and environmentalists, soya and beef from recently cleared land. The all with competing agendas. This has led to some criticism that round tables provide political cover for companies that wish to avoid making stronger commitments to the environment.

"It's my contention that the round tables are holding back innovation," says Scott Poynton, executive director of the Forest Trust, a nonprofit organization in Crassier, Switzerland, which has been working with Swiss food company Nestlé and the world's second-largest palm-oil producer, Golden Agri-Resources in Indonesia, to enforce their zero-deforestation commitments. Companies that want to halt deforestation should pressure their suppliers directly, Poynton says. "The model is there," he says, "and it doesn't require the vast billions of dollars everybody is talking about."

Instead, the round tables are intended to help propagate minimum environmental standards across the entire world. "It takes a while before you have all of the companies aligned on these principles," says Jeroen Douglas, South American programme director for the Solidaridad network in Buenos Aires, which focuses on sustainable supply chains. Solidaridad plans to invest around $€ 70$ million (US\$94 million) to help some 400,000 small-scale farmers and ranchers to achieve round-table certification by 2015 . But there are barriers, and Douglas says that the link with REDD money might be enough to seduce local producers.

Other efforts are also emerging. For example, a coalition of state-level governments in the United States, Brazil, Indonesia, Nigeria, Peru and Mexico has launched its own initiative, the Governors' Climate and Forests Task Force. It is working to set up mechanisms that would allow companies in participating regions to offset emissions by paying to reduce deforestation.

William Boyd, a law professor at the University of Colorado in Boulder and project leader for the task force, says that both the roundtable and state efforts are emblematic of what is needed. If the money to transform agriculture and reduce the incentives for clearing forests doesn't begin to flow soon, farmers in the developing world will give up on the process, Boyd says. "And who could blame them?"

\footnotetext{
1. Rudorff, B. F. T. et al. Remote Sens. 3, 185-202 (2011).

2. Macedo, M. N. et al. Proc. Natl Acad. Sci. USA 109, 1341-1346 (2012).
}

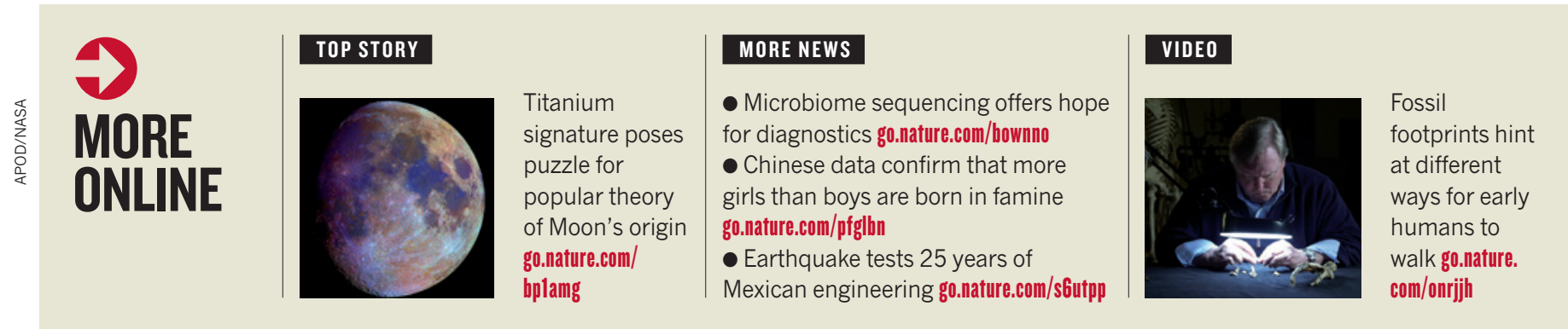

